See discussions, stats, and author profiles for this publication at: https://www.researchgate.net/publication/324794543

\title{
Analisis aliran fluida dan insulasi aliran pipa bawah laut menggunakan pipesim
}

Article · April 2018

CITATIONS

0

2 authors, including:

Rosyida Permatasari

Universitas Trisakti

31 PUBLICATIONS 6 CITATIONS

SEE PROFILE
READS

100 


\title{
Analisis aliran fluida dan insulasi aliran pipa bawah laut menggunakan pipesim
}

\author{
Rivandy Fathur Rachman, ${ }^{1}$ dan Rosyida Permatasari ${ }^{1}$ \\ ${ }^{1}$ Jurusan Teknik Mesin, Fakultas Teknologi Industri, Universitas Trisakti, Kyai Tapa No.1 Grogol, Indonesia \\ Email korespondensi: tsukarnoto@trisakti.ac.id
}

\begin{abstract}
Abstrak
Produksi black oil yang mengalir dari reservoir selalu dipengaruhi oleh kejenuhan air dan merupakan masalah umum yang terutama terjadi dalam pipa bawah laut yang dapat membentuk senyawa hidrat. Pembentukan senyawa hidrat di dalam pipa bawah laut merupakan masalah yang umum terjadi karena penurunan suhu yang signifikan dan perubahan termodinamika saat produksi. Masalah tersebut seharusnya dapat dicegah secara efektif untuk menjamin pengoperasian jalur perpipaan secara normal. Tujuan dari penelitian ini adalah untuk mengetahui cara mengurangi pembentukan senyawa tersebut yang dapat menghambat proses pengangkutan pada pipa bawah laut melalui penggunaan berbagai macam material insulasi. Jenis-jenis material insulasi yang diuji adalah Polietilena dengan kerapatan rendah (Polyethylene Low-Density/LDPE), Poliuretana (Polyurethane /PU), Polypropelene (PP), Polistirena (Polystyrene /PS), Polytetraflouroethylene yang diisi dengan kaca (PTFE 25\% GF). Persamaan perpindahan kalor aliran fluida pada kondisi stabil dan rata-rata kehilangan kalor digunakan dalam model perangkat lunak PIPESIM untuk menganalisa pemilihan material insulasi yang dibutuhkan dalam pencegahan pembentukan senyawa tersebut yang terjadi didalam pipa bawah laut. Hasil penelitian menyatakan bahwa material terbaik dari kelima material insulasi yang dipakai adalah Polistirena (PS), sedangkan material terburuk adalah Polytetraflouroethylene yang diisi dengan kaca (PTFE 25\%GF).
\end{abstract}

Kata kunci: aliran minyak pipa bawah laut, senyawa hidrat, material insulasi, pertukaran kalor

\begin{abstract}
Black oil production that flows from the reservoir is always affected by water saturation and is a common problem that mainly occurs in the subsea pipeline that can form hydrate compounds. The formation of hydrate compounds in the subsea pipeline is a common problem due to significant temperature drop and thermodynamic changes during production. The problem should be effectively prevented to ensure normal pipeline operation. The purpose of this study is to find out how to reduce the formation of such compounds which can inhibit the transport process in the subsea pipeline through the use of various kinds of insulation material. The types of insulation materials tested are Polyethylene Low-Density (LDPE), Polyurethane (PU), Polypropelene (PP), Polystyrene (PS) and Polytetraflouroethylene filled with Glass (PTFE 25\% GF). The fluid flow heat transfer equation in stable condition and mean heat loss is used in PIPESIM software model to analyze the selection of the insulation material required in the prevention of the formation of such compounds occurring within the subsea pipeline. The results stated that the best material of the five insulation materials used is Polystyrene (PS), whereas the worst material is Polytetraflouroethylene filled with Glass (PTFE 25\% GF).
\end{abstract}

Keywords: subsea pipeline oil flow, hydrate compound, insulation material, heat exchange

\section{Pendahuluan}

Bertambahnya permintaan minyak dan gas membuat dunia semakin mencari sumber minyak dan gas di kedalaman laut, bahkan semakin dalam mencari ke dasar laut dan semakin gencar memproduksi dalam beberapa tahun terakhir ini. Minyak dan gas mengalir dari reservoir, menuju sumur dan diangkut ke daratan melalui pipa bawah laut. Dalam perjalanan dari reservoir ke kepala sumur, proses penurunan suhu fluida berlangsung lambat karena bebatuan yang hangat. Disisi lain penurunan suhu semakin cepat ketika fluida mulai memasuki pipa bawah laut, karena suhu air laut yg rendah. Suhu pipa bawah laut harus dipertahankan karena minyak dan gas memiliki kecenderungan menumpuk senyawa lilin atau hidrat. Jika suhu minimal tidak dipertahankan, maka tumpukan hidrat akan semakin banyak dan dapat menghambat jalur pengangkutan minyak dan gas, yang dapat berakibat penurunan hasil produksi, bahkan dapat menghentikan produksi. Hal ini dapat mempengaruhi investasi teknologi utama dalam desain jalur aliran untuk mengontrol dan mencegah terjadinya kehilangan suhu yang menjamin aliran yang stabil.

Oleh karena itu dibutuhkan suatu sistem yang memungkinkan untuk menjaga kestabilan suhu fluida untuk menjaga pembentukan senyawa-senyawa solid yang dapat mengganggu proses pengangkutan fluida tersebut [1].

Tantangan dalam pengoperasian perpipaan dari minyak dan gas adalah resiko yang terkait dengan 
pengangkutan fluida tersebut. Ketika air, minyak dan gas yang mengalir serentak didalam jalur pipa, terdapat peluang yang cukup tinggi untuk air dan fluida hidrokarbon dapat membentuk endapan senyawa hidrat seperti lilin dan asphaltene diatas permukaan dalam pipa dan secara bertahap dapat menghalangi aliran di dalam pipa. Kehadiran air, perubahan tekanan dan suhu disepanjang jalur perpipaan dapat menyebabkan korosi internal sehingga proses operasional menjadi terganggu.

Tantangan terbesar yang dihadapi insinyur adalah bagaimana mendesain jalur perpipaan yang menjamin pengangkutan fluida dari reservoir menuju hilir pabrik pengolahan berjalan dengan aman dan lebih ekonomis. Pengetahuan mengenai sifat dinamika fluida dan analisa thermal hydraulic yang tepat bagi sistem dibutuhkan untuk mengembangkan strategi dalam mengontrol senyawa solid seperti hidrat, lilin, asphaltene dan terkadang permasalahan kerak dan pasir [1].

Pada pengoperasian kondisi stabil, suhu produksi fluida berkurang sejalan saat proses pemindahan atau kehilangan kalor yg disebabkan dari lingkungan sekitar dinding pipa. Profil suhu dalam jalur perpipaan harus lebih tinggi dibanding suhu yg diperlukan untuk mencegah pembentukan senyawa lilin dan hidrat saat pengoprasian kondisi normal dan ditentukan dari aliran stabil dan pehitungan perpindahan kalor yang terjadi. Kondisi aliran stabil dapat juga terganggu dikarenakan pemberhentian dan pengulangan kembali operasi, seperti contoh analisa perpindahan kalor pada kondisi stedi (steady) dan transien (transient) pada sistem dijalankan untuk mengetahui suhu dari fluida yang mengalir [1].

Kepastian aliran fluida merupakan analisa teknik secara menyeluruh untuk menjamin pengangkutan fluida hidrokarbon tersebut berjalan secara aman dan ekonomis di setiap lingkungan yang dilalui. Aliran fluida dari minyak dan gas tanpa hambatan merupakan kunci kesuksesan industri perminyakan. Saat ini, pengunaan sistem multifase (multiphase) untuk memproduksi dan mengangkut fluida untuk jarak jauh sedang berkembang. Terlepas dari itu, selalu ada masalah dalam pembentukan senyawa solid yang menyebabkan penghambatan aliran dan korosi. Oleh karena itu, pengaturan aliran fluida harus dapat mengurangi bahkan mengeleminasi masalah-masalah potensial yang akan terjadi [2]/

Penelitian yang telah dilakukan ini membahas tentang pencegahan pembentukan senyawa-senyawa yang dapat menghambat proses pengangkutan fluida hidrokarbon pada pipa bawah laut, serta melakukan simulasi melalui perangkat lunak PIPESIM menggunakan persamaan-persamaan perpindahan kalor dan analisis masalah-masalah yang terjadi pada proses pengangkutan fluida.

\section{Metode}

\section{Pertimbangan Desain}

Banyak pertimbangan dalam menentukan desain yang efektif untuk pengaturan aliran fluida di setiap lingkungan yang didapat. Pengaturan aliran fluida harus mempertimbangkan setiap kapabilitas dan kebutuhan untuk setiap bagian dari sistem agar proses produksi berjalan dengan lancar [1].

Faktor-faktor yang harus diperhatikan dalam pengaturan aliran fluida adalah sebagai berikut:

- Karakteristik reservoir dan profil produksi,

- Sifat-sifat fluida yang dihasilkan,

- Diameter alir,

- Maksimal dan minimum dari aliran rata-rata produksi,

- Insulasi,

- Injeksi kimiawi dan penyimpanan yang dibutuhkan,

- Fasilitas dari Host yang dibutuhkan (pigging, penyimpanan fluida, intervensi, kapabilitas, penerima aliran) dan

- Biaya operasi.

\section{Perpindahan kalor}

Perpindahan kalor adalah salah satu dari displin ilmu teknik termal yang mempelajari cara menghasilkan kalor, menggunakan kalor, mengubah kalor, dan menukarkan kalor di antara sistem fisik. Perpindahan kalor diklasifikasikan menjadi konduktivitas termal, konveksi termal, radiasi termal, dan perpindahan kalor melalui perubahan fasa.

Nilai perpindahan kalor (q) dapat diperoleh melalui Persamaan (1) sebagai berikut [3]:

$\mathrm{q}=\mathrm{m} \times \mathrm{C} \times \Delta \mathrm{T}$

Dimana, m adalah massa dari fluida tersebut;

$\mathrm{C}$ adalah kapasitas kalor spesifik fluida; dan $\Delta \mathrm{T}$ adalah perubahan kalor yang terjadi pada system tersebut.

\section{Tahanan Termal Pipa}

Konduksi yang dipakai pada pipa bawah laut yang dilapisi oleh material insulasi merupakan konduksi silinder berlapis yang dapat dianalogikan seperti resistansi listrik yang biasa disebut dengan resistansi kalor $\left(\mathrm{R}_{\mathrm{k}}\right)$ yang dapat dituliskan dengan Persamaan (2) sebagai berikut [3] :

$R_{k}=\frac{\ln \left(\frac{r_{0}}{r_{i}}\right)}{k .2 \pi \cdot L}$

Namun, dikarenakan pada penelitian ini dipakai konduksi silinder berlapis menggunakan dua buah $R_{k}$, sehingga memiliki nilai $\mathrm{R}_{\mathrm{ktot}}$ yang dapat ditulis dengan Persamaan (3) sebagai berikut [3] 
$R_{k t o t}=\frac{\ln \left(\frac{r_{2}}{r_{1}}\right)}{k_{A} \cdot 2 \pi \cdot L}+\frac{\ln \left(\frac{r_{3}}{r_{2}}\right)}{k_{B} \cdot 2 \pi \cdot L}$

Dimana:

$\mathrm{k}_{\mathrm{A}}$ adalah konduktivitas termal benda $\mathrm{A}$

$\mathrm{k}_{\mathrm{B}}$ adalah konduktivitas termal benda $\mathrm{B}$

$\mathrm{r}_{1}$ adalah jari-jari dalam silinder

$\mathrm{r}_{2}$ adalah jari-jari lapisan kedua silinder

$\mathrm{r}_{3}$ adalah jari-jari terluar dari silinder

$\mathrm{L}$ adalah panjang silinder.

Gambar 1 memperlihatkan gambar silinder berlapis yang merupakan model dari aliran pipa yang digunakan pada penelitian ini.

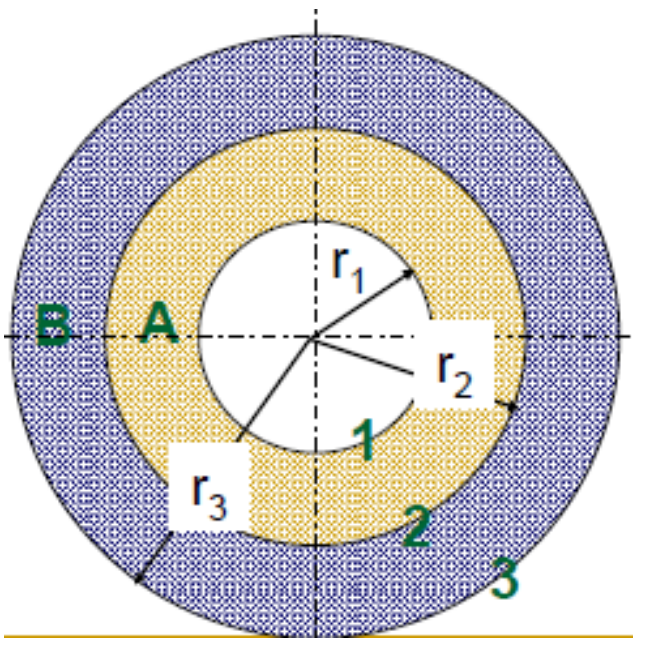

Gambar 1. Silinder berlapis [3]

Dengan Persamaan (3) serta perubahan temperatur yang terjadi $(\Delta \mathrm{T})$ maka dapat diperoleh perpindahan kalor (q) yang terjadi yang dapat dituliskan dengan Persamaan (4) sebagai berikut[3]:

$$
q=\frac{\Delta T}{R_{k t o t}}
$$

\section{Konveksi}

Diketahui bahwa bagian dalam dan luar pipa bersinggungan dengan fluida, pada bagian luar pipa bersinggungan dengan air laut, dan pada bagian dalam pipa bersingungan dengan fluida hidrokarbon. Perbedaan suhu antara permukaan pipa dengan suhu fluida menyebabkan perpindahan kalor secara konveksi. Persamaan konveksi fluida yang terjadi dapat dituliskan sebagai berikut [3]:

$\mathrm{q}=\mathrm{h}_{\mathrm{f}} \times \mathrm{A} \times \Delta \mathrm{T}$

$\mathrm{h}_{\mathrm{f}}$ adalah nilai konveksi dari fluida tersebut.

\section{Insulasi}

Insulasi merupakan pilihan terbaik untuk mempertahankan kalor dan menjaga suhu operasi diluar dari daerah hidratnya serta untuk meminimalisir kehilangan kalor. Insulasi termal adalah metode atau proses yang digunakan untuk mengurangi laju perpidahan kalor. Kemampuan insulasi suatu bahan diukur dengan konduktivitas termal (k). Konduktivitas termal yang rendah setara dengan kemampuan insulasi (resistansi termal atau nilai R) yang tinggi. Dalam teknik termal, sifat-sifat lain suatu bahan insulator atau isolator adalah densitas ( $\rho)$ dan kapasitas kalor spesifik (C). Tabel 1 memperlihatkan sistem pelapisan untuk insulasi termal pemipaan.

Tabel 1. Sistem pelapisan yang memungkinkan untuk insulasi termal pemipaan [4]

\begin{tabular}{|l|ll|lr|}
\hline $\begin{array}{l}\text { Garis } \\
\text { Aliran }\end{array}$ & $\begin{array}{l}\text { Temper } \\
\text { atur }\left({ }^{\circ} \mathrm{C}\right)\end{array}$ & Sistem Insulasi \\
\hline $\begin{array}{l}\text { Temper } \\
\text { atur } \\
\begin{array}{l}\text { Rendah } \\
-10\end{array}\end{array}$ & to & $\begin{array}{l}\text { Polyurethane } \\
\text { Polypropylene (PP) } \\
\text { Filled rubbers, syntactic foams } \\
\text { based on epoxy and } \\
\text { Polyurethanes }\end{array}$ \\
\hline $\begin{array}{l}\text { Temper } \\
\text { atur } \\
\text { Sedang }\end{array}$ & $\begin{array}{l}70 \\
120\end{array}$ & to & $\begin{array}{l}\text { PP, rubber, Syntactic epoxy } \\
\text { foams }\end{array}$ \\
\hline $\begin{array}{l}\text { Temper } \\
\text { atur } \\
\text { Tinggi }\end{array}$ & $\begin{array}{l}120 \\
200\end{array}$ & to & $\begin{array}{l}\text { PP systems, Phenolic foams, } \\
\text { PIP with polyurethane foam or } \\
\text { inorganic insulating materials }\end{array}$ \\
\hline
\end{tabular}

Untuk data dan dimensi dari pemodelan pipa sederhana tanpa insulasi di dalam air dapat dilihat pada Tabel 2 dan data dari fluida yang digunakan dapat dilihat pada Tabel 3.

Tabel 2. Data dan Dimensi Pemodelan Pipa Sederhana

\begin{tabular}{|l|l|l|l|}
\hline No & Dimensi & Ukuran & Satuan \\
\hline 1 & $\begin{array}{l}\text { Diameter dalam pipa, } \\
\mathrm{D}_{0}\end{array}$ & 254 & $\mathrm{~mm}$ \\
\hline 2 & $\begin{array}{l}\text { Ketebalan Dinding } \\
\text { Pipa, t }\end{array}$ & 12.7 & $\mathrm{~mm}$ \\
\hline 3 & Panjang Pipa, L & 2000 & $\mathrm{~m}$ \\
\hline 4 & Tekanan Inlet & 1000 & $\mathrm{psig}$ \\
\hline 5 & $\begin{array}{l}\text { Kekasaran } \\
\text { Permukaan, f }\end{array}$ & 0.0254 & $\mathrm{n}$ \\
\hline 6 & $\begin{array}{l}\text { Konduktivitas } \\
\text { Termal Pipa, } \mathrm{k}_{\mathrm{p}}[5]\end{array}$ & 60.55 & $\mathrm{~W} / \mathrm{m} . \mathrm{K}$ \\
\hline
\end{tabular}

Gas Oil Ratio (GOR) pada Tabel 3 merupakan perbandingan rasio kandungan gas dan minyak pada Black Oil. Jika nilai GOR $=0$, maka dapat disebut sebagai Dead Oil karena tidak mengandung gas sama sekali. SG atau specific gravity atau biasa kita sebut sebagai densitas atau massa jenis. Dalam dunia perdagangan terutama yang dikuasai oleh perusahaan Amerika, Gravitasi jenis atau lebih sering disingkat dengan SG ini dinyatakan API Gravity dan juga API (American Petroleum Institute) yang sangat mirip dengan Baume gravity. 
Baume gravity adalah suatu besaran yang merupakan fungsi dari berat jenis yang dapat dinyatakan dengan persamaan:

$$
\begin{aligned}
& { }^{0} A P I=\frac{141.5}{S G}-131.5 \\
& S G=\frac{141.5}{131.5+{ }^{0} A P I}
\end{aligned}
$$

API Gravity minyak bumi sering menunjukan kualitas dari minyak bumi tersebut. Makin kecil SG-nya atau makin tinggi API-nya maka minyak bumi tersebut makin berharga karena lebih banyak mengandung bensin. Sebalik nya makin rendah API atau makin besar SG-nya, maka mutu minyak itu kurang baik karena lebih banyak mengandung lilin.

Penelitian ini menggunakan tiga tempat yang berbeda sebagai acuan dalam pengambilan data simulasi. Pada ketiga tempat tersebut memiliki data kelautan yang berbeda. agar mempersempit ruang lingkup maka penelitian akan dilakukan pada kedalaman dua ratus meter $(200 \mathrm{~m})$ dari permukaan laut. Tabel 4 menunjukkan data kelautan yang digunakan pada penelitian ini.

Tabel 3. Komposisi Black Oil

\begin{tabular}{|l|l|l|l|l|}
\hline No & Komposisi & Nilai & Satuan & Notasi \\
\hline 1 & Kadar Air & 20 & $\%$ & $\mathrm{~W}_{\text {cut }}$ \\
\hline 2 & Gas Oil Ratio & 0 & $\mathrm{~m}^{3} / \mathrm{m}^{3}$ & $\mathrm{GOR}$ \\
\hline 3 & SG Air & 1.02 & - & $\mathrm{SG}_{\text {air }}$ \\
\hline 4 & API & 30 & ${ }^{0} \mathrm{API}$ & API \\
\hline 5 & Debit Fluida & 0.018 & $\mathrm{~m}^{3} / \mathrm{s}$ & $\mathrm{Q}_{\text {fluida }}$ \\
\hline 6 & $\begin{array}{l}\text { Kapasitas } \\
\text { Kalor }\end{array}$ & 1884.05 & $\mathrm{~J} / \mathrm{kg} . \mathrm{K}$ & $\mathrm{Cp}$ \\
\hline 7 & $\begin{array}{l}\text { Konduktivitas } \\
\text { Termal Fluida }\end{array}$ & 0.1384 & $\mathrm{~W} / \mathrm{m} . \mathrm{K}$ & $\mathrm{k}_{\mathrm{f}}$ \\
\hline 8 & $\begin{array}{l}\text { Viskositas } \\
\text { Fluida }\end{array}$ & 0.0366 & $\mathrm{~kg} / \mathrm{m} . \mathrm{s}$ & $\mu$ \\
\hline 9 & Suhu Fluida & 28 & ${ }^{0} \mathrm{C}$ & $\mathrm{Tf}_{0}$ \\
\hline
\end{tabular}

(American Petroleum Institute - API)

\begin{tabular}{|c|c|c|c|}
\hline $\begin{array}{l}\text { Nama } \\
\text { Tempat }\end{array}$ & $\begin{array}{l}\text { Suhu Laut } \\
\text { pada } \\
\text { Kedalaman } \\
200 \mathrm{~m}, \quad \mathrm{~T}_{\mathrm{x}} \\
\left({ }^{0} \mathrm{C}\right)\end{array}$ & $\begin{array}{l}\text { Kecepatan } \\
\text { Aliran Air } \\
\text { Laut rata- } \\
\text { rata, } \\
(\mathrm{m} / \mathrm{s})\end{array}$ & $\begin{array}{l}\text { Massa } \\
\text { Jenis } \\
\text { Air } \\
\text { Laut, } \\
\text { SG }_{\text {air }}\end{array}$ \\
\hline $\begin{array}{l}\text { Port Heglig- } \\
\text { Sudan [6] }\end{array}$ & 4 & 0.0348 & 1.0208 \\
\hline $\begin{array}{l}\text { Port } \\
\text { Harcourt - } \\
\text { Nigeria } \\
{[5]}\end{array}$ & 10 & 0.04012 & 1.0206 \\
\hline
\end{tabular}

Tabel 4. Data Kelautan Penelitian

\begin{tabular}{|l|l|l|l|}
\hline $\begin{array}{l}\text { Bombaii } \\
\text { High - India } \\
{[1]}\end{array}$ & 15 & 0.03109 & 1.0202 \\
\hline
\end{tabular}

Pada penelitian ini menggunakan lima jenis material insulasi termal yaitu: Polietilena dengan kerapatan rendah (Polyethylene Low-Density/LDPE), Poliuretana (Polyurethane /PU), Polypropelene (PP), Polistirena (Polystyrene /PS), Polytetraflouroethylene yang diisi dengan kaca (PTFE 25\% GF) dengan ketebalan $\left(\mathrm{t}_{\mathrm{i}}\right) \quad 35 \mathrm{~mm}$ yang memiliki nilai konduktivitas termal masing-masing (Tabel 5).

Tabel 5. Nilai Konduktivitas Termal Material Insulasi [1]

\begin{tabular}{|l|l|}
\hline Material insulasi & $\begin{array}{l}\text { Konduktivitas } \\
\text { Termal } \\
\text { (W/m.K) }\end{array}$ \\
\hline $\begin{array}{l}\text { Polyethylene Low-Density } \\
\text { (LDPE) }\end{array}$ & 0.33 \\
\hline Polypropelene (PP) & 0.15 \\
\hline Polyurethane (PU) & 0.23 \\
\hline Polystyrene (PS) & 0.10 \\
\hline $\begin{array}{l}\text { Polytetraflouroethylene filled } \\
\text { with Glass (PTFE 25\% GF) }\end{array}$ & 0.42 \\
\hline
\end{tabular}

\section{Hasil dan Pembahasan}

\section{Suhu dan Tekanan Aliran Fluida Pada Aliran PipaTanpa Material Insulasi}

Berdasarkan hasil dari simulasi menggunakan PIPESIM, diperoleh data suhu (Gambar 1) dan tekanan (Gambar 2) fluida pada aliran pipa tanpa insulasi termal.

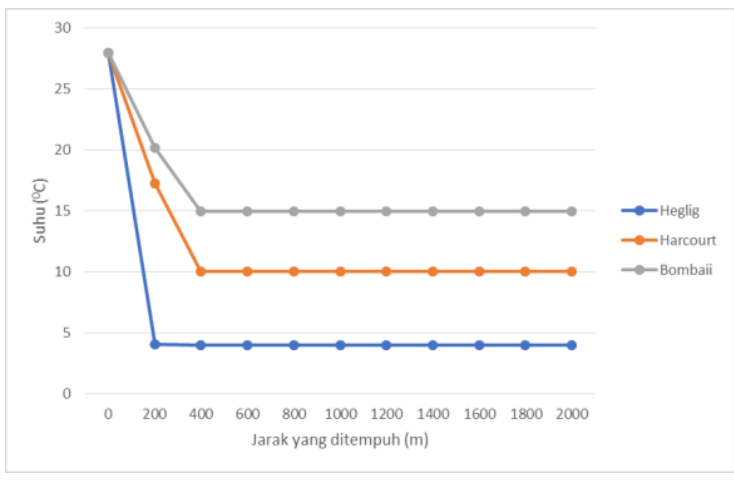

Gambar 1. Pengaruh jarak tempuh aliran fluida terhadap suhu fluida pada aliran pipa tanpa insulasi termal

Dari Gambar 1, dapat dilihat perubahan suhu yang signifikan di masing-masing tempat. Hal ini disebabkan oleh tidak adanya insulasi termal sepanjang aliran pipa tersebut. Sehingga suhu fluida dengan cepat menurun hingga sama dengan suhu lingkungan disekitarnya $\left(\mathrm{T}_{\infty}\right.$ di Heglig $4^{0} \mathrm{C} ; \mathrm{T}_{\infty}$ di Harcourt $10^{\circ} \mathrm{C}$ dan $\mathrm{T}_{\infty}$ di Bombaii High $15^{\circ} \mathrm{C}$ ). 
Semakin rendah suhu lingkungannya, maka semakin besar penurunan suhu dari fluida tersebut. Dan dapat dilihat pula pada grafik perubahan tekanan (Gambar 2) bahwa penurunan tekanan yang cukup signifikan terjadi pada Port-Heglig yang memiliki suhu lingkungan yang rendah.

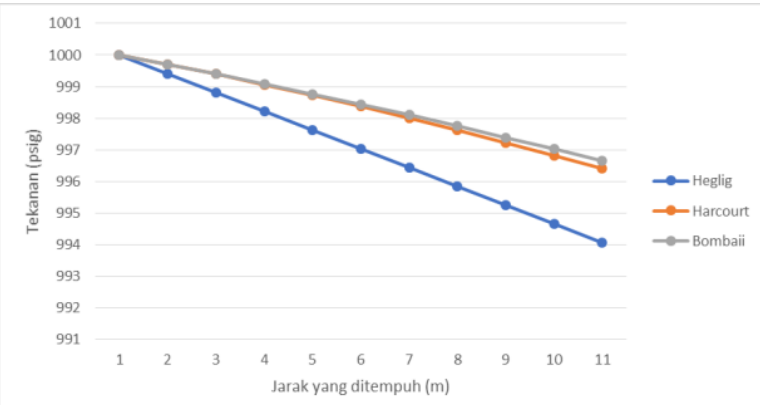

Gambar 2. Pengaruh jarak tempuh aliran fluida terhadap penurunan tekanan fluida pada aliran pipa tanpa insulasi termal

\section{Suhu dan Tekanan Aliran Fluida Pada Aliran Pipa Menggunakan Material Insulasi}

Berdasarkan hasil dari simulasi menggunakan PIPESIM, Gambar 3 dan Gambar 4 menunjukkan data suhu dan tekanan fluida pada aliran pipa yang menggunakan insulasi termal di Port Heglig - Sudan. Sedangkan Gambar 5 dan Gambar 6 menunjukkan data suhu dan tekanan fluida pada aliran pipa yang menggunakan insulasi termal di Port Harcourt Nigeria. Selain itu, diperlihatkan juga data suhu (Gambar 7) dan tekanan (Gambar 8) fluida pada aliran pipa yang menggunakan insulasi termal di Bombaii High - India.

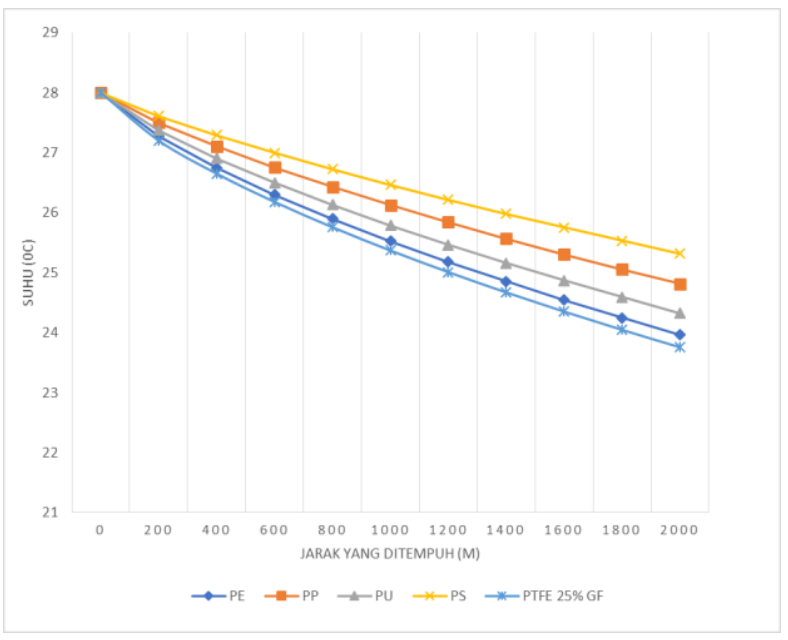

Gambar 3. Pengaruh jarak tempuh aliran fluida terhadap suhu fluida pada aliran pipa untuk setiap material insulasi di Port Heglig - Sudan

Gambar 3, 5 dan 7 menunjukan perbedaan penurunan temperatur yang berbeda untuk masing-masing material insulasi (PE, PP, PU, PS dan PTFE 25\%), walaupun berada didalam suhu lingkungan yang sama. Hal ini disebabkan karena nilai konduktivitas termal masing-masing material yang berbeda. Dengan nilai konduktivitas termal (k) dari PTFE25\%GF paling besar $(\mathrm{k}=0,42 \mathrm{~W} / \mathrm{m} . \mathrm{K})$, sedangkan nilai $\mathrm{k}$ dari PS paling kecil $(\mathrm{k}=0,1 \mathrm{~W} / \mathrm{m} . \mathrm{K})$. Hal ini menunjukkan bahwa semakin kecil nilai $\mathrm{k}$ dari suatu material maka semakin kecil penurunan temperatur yang terjadi. Sedangkan nilai tekanan juga mengalami perubahan tekanan akibat jarak tempuh dari aliran fluida untuk masing-masing material insulasi (Gambar 4, 6 dan 8), walaupun tidak terlalu signifikan.

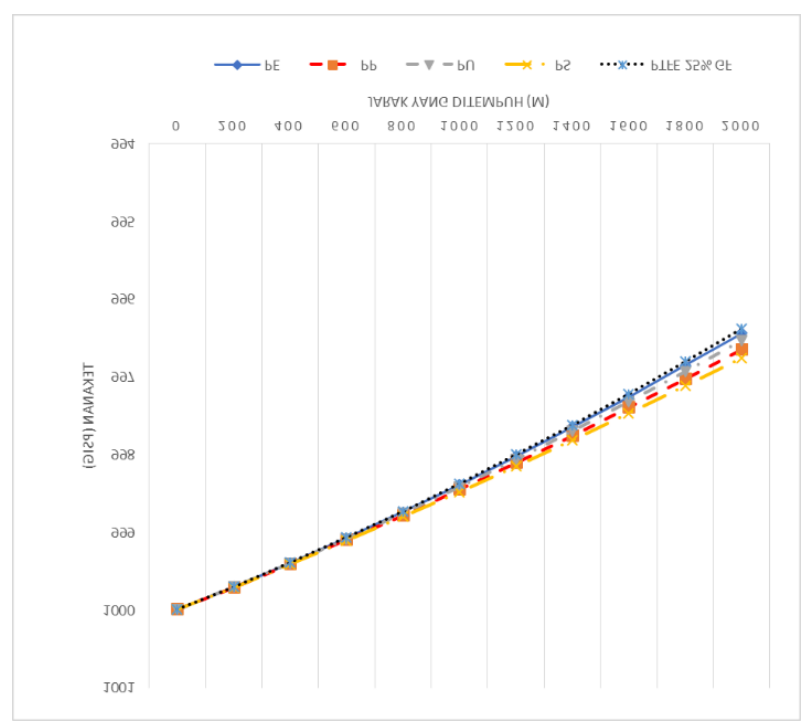

Gambar 4. Pengaruh jarak tempuh aliran fluida terhadap tekanan fluida pada aliran pipa untuk setiap material insulasi di Port Heglig - Sudan

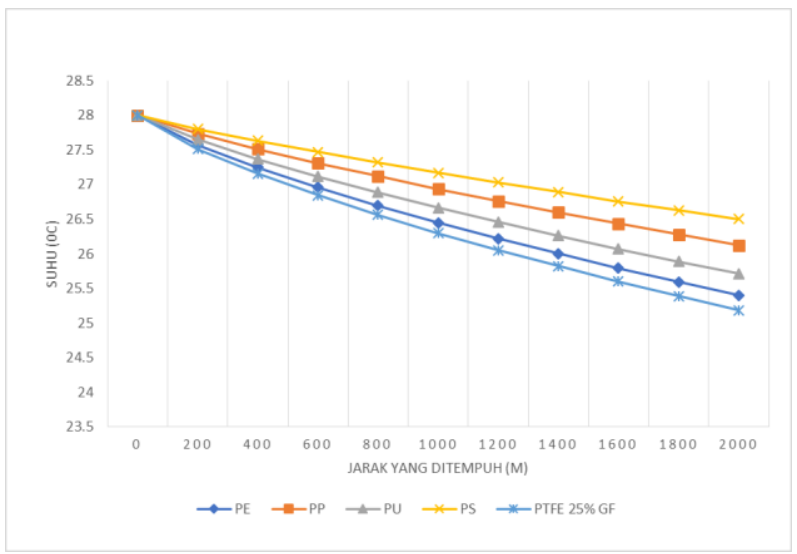

Gambar 5. Pengaruh jarak tempuh aliran fluida terhadap suhu fluida pada aliran pipa untuk setiap material insulasi di Port Harcourt - Nigeria 


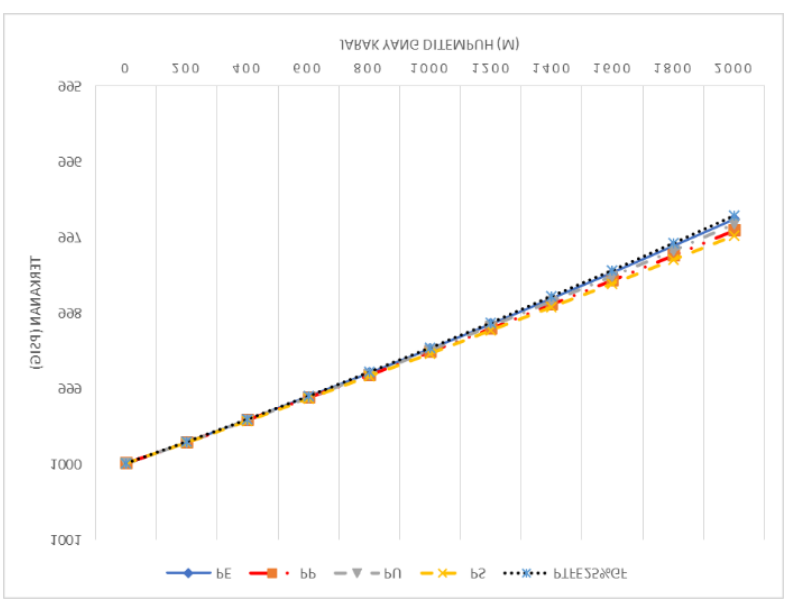

Gambar 6. Pengaruh jarak tempuh aliran fluida terhadap tekanan fluida pada aliran pipa untuk setiap material insulasi di Port Harcourt - Nigeria

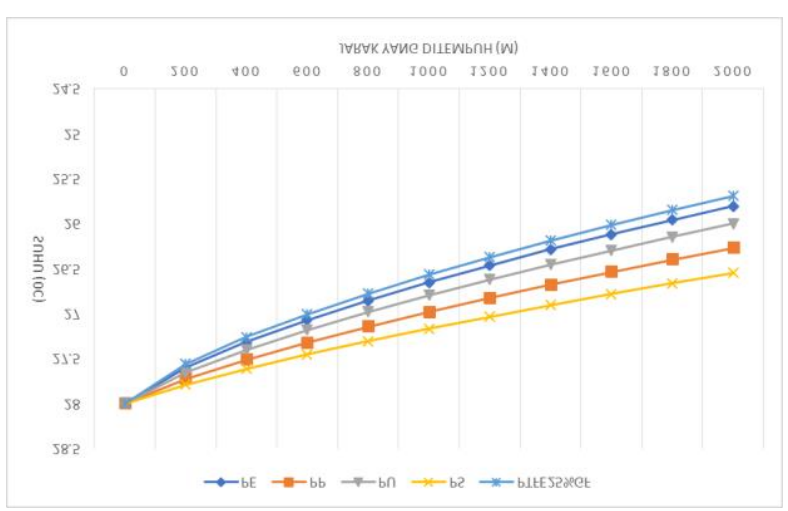

Gambar 7. Pengaruh jarak tempuh aliran fluida terhadap suhu fluida pada aliran pipa untuk setiap material insulasi di Bombaii High - India

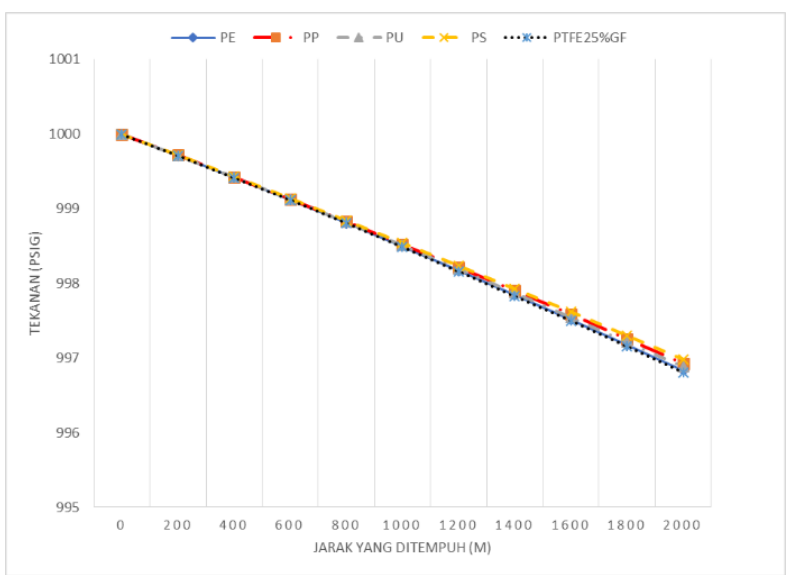

Gambar 8. Pengaruh jarak tempuh aliran fluida terhadap tekanan fluida pada aliran pipa untuk setiap material insulasi di Bombaii High - India

\section{Terbentuknya Endapan Senyawa Hidrat di Port Heglig-Sudan}

Setelah didapatkan data-data perubahan suhu, maka dapat diketahui ketebalan endapan dari senyawa hidrat melalui simulasi dengan PIPESIM untuk waktu pengaliran fluida selama 72 jam, kemudian data-data yang didapat akan dibandingkan berdasarkan tempat fluida tersebut dialirkan (Gambar 9).

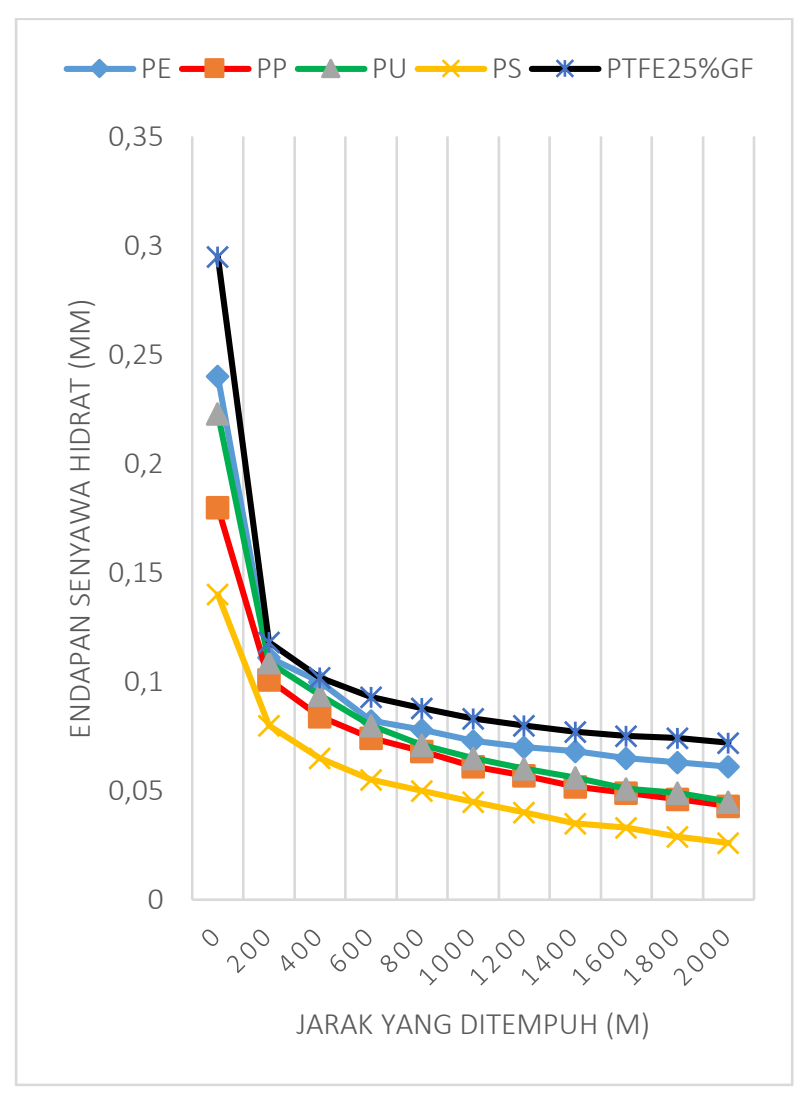

Gambar 10. Pengaruh jarak tempuh aliran fluida terhadap terbentuknya endapan senyawa hidrat pada aliran pipa untuk setiap material insulasi di Port Heglig-Sudan

Gambar 10 memperlihatkan bahwa terbentuknya endapan senyawa hidrat pasti akan terjadi, namun dapat dikurangi. Penurunan suhu mulai stabil pada jarak 200m (Gambar 3) sesuai dengan endapan yang dihasilkan mulai stabil pada jarak yang sama (Gambar 10). Hal ini menunjukkan bahwa kestabilan suhu berpengaruh terhadap pembentukan endapan senyawa hidrat tersebut. Jika nilai perubahan suhu semakin besar, maka ketebalan endapan senyawa hidrat akan semakin besar. Sedangkan, jika perubahan suhu semakin kecil (stabil), maka ketebalan endapan senyawa hidrat tersebut akan semakin kecil pula. Gambar 10 juga memperlihatkan bahwa nilai endapan paling besar terjadi pada saat penggunaan PTFE $25 \%$ GF yang memiliki nilai $\mathrm{k}=0,42 \mathrm{~W} / \mathrm{m}$. K. Hal tersebut terjadi karena saat penggunaan PTFE 25\%GF sebagai material insulasi, nilai perubahan suhu yang terjadi paling besar dibandingkan dengan penggunaan material yang lainnya. Sedangkan, pada saat penggunaan PS yang memiliki nilai $\mathrm{k}=0,1 \mathrm{~W} / \mathrm{m} . \mathrm{K}$, ketebalan endapan senyawa hidrat yang didapat paling tipis dibanding dengan penggunaan material insulasi lainnya, karena nilai perubahan suhu yang terjadi merupakan yang paling kecil. Hal ini menunjukkan bahwa pemilihan material insulasi juga 
berpengaruh pada besarnya ketebalan senyawa hidrat yang didapat pada jalur perpipaan bawah laut. Pernyataan ini sesuai dengan hasil penelitian yang telah dilakukan oleh Okologume [5].

\section{Kesimpulan}

Berdasarkan hasil diskusi dan analisa data yang diperoleh, maka dapat disimpulkan beberapa hal sebagai berikut:

1. Pemilihan material insulasi sangat berpengaruh terhadap besarnya laju perubahan suhu fluida yang diangkut.

2. Pemilihan material insulasi sangat berpengaruh kepada pembentukan endapan senyawa-senyawa hidrat yang dapat menghambat proses pengangkutan pada jalur perpipaan bawah laut.

3. Material insulasi yang terbaik adalah Polistirena (PS), sedangkan material terburuk adalah Polytetraflouroethylene yang diisi dengan kaca (PTFE 25\%GF).

4. Semakin rendah nilai konduktivitas material maka insulasi yang terjadi akan semakin baik. Sebaliknya, semakin tinggi nilai konduktivitas material maka insulasi yang terjadi akan semakin buruk.

\section{Ucapan Terima Kasih}

Ucapan terima kasih diucapkan pada Universitas Trisakti khususnya Jurusan Teknik Mesin Fakultas Teknologi Industri yang telah memberikan dukungan untuk menyelesaikan penelitian ini

\section{Daftar Pustaka}

[1] S. Sadafule, \& K. D. Patil, (2014). Study on Effect of Insulation Design on ThermalHydraulic Analysis: An Important Aspect in Subsea Pipeline Designing. Journal of Petroleum Engineering and Technology I, 4(1), 33-45.

[2] O. J. Romero, H. C. Saad, I. B. Pereira, \& M. I. Romero, (2016). Influence of heat transfer on two-phase flow behavior in onshore oil pipelines. INGENIERÍA E INVESTIGACIÓN, 36(1), 14-22.

[3] J. P. Holman, (2010). Heat Transfer. McGrawhill.

[4] Q. B. Yong Bai, (2012). Subsea Engineering Handbook. New York: GPP: Gulf Professional Publishing.

[5] O.Wilfred, \& D. Appah, (2015). Analyzing Thermal Insulation for Effective Hydrate Prevention in Conceptual Subsea Pipeline Design. International Journal of Current Engineering and Technology, 5(4), 2492-2499.

[6] M. E. Mohyaldinn, R. Hamid, M. Adil, \& O. Musa, (2016). Sudy OF The Effect Of Flow Modifiers On The Operation Of Heglig - Port Sudan Pipeline. ARPN Journal of Engineering and Applied Sciences, 11(1), 259-267. 